\title{
RETURN OF BEACH-NESTING SNOWY PLOVERS TO LOS ANGELES COUNTY FOLLOWING A 68-YEAR ABSENCE
}

THOMAS PATRICK RYAN, Ryan Ecological Consulting, 526 West Colorado Blvd., Monrovia, California 91016; tryanbio@gmail.com

STACEY VIGALlON, Los Angeles Audubon, P.O. Box 411301, Los Angeles, California 90041

DANIEL STEVEN COOPER, Cooper Ecological Monitoring, 255 Satinwood Ave., Oak Park, California 91377

CHRIS DELLITH, U.S. Fish and Wildlife Service, Ventura Field Office, 2493 Portola Rd. Suite B, Ventura, California 93003

KARINA JOHNSTON, The Bay Foundation, 8334 Lincoln Blvd., \#310, Los Angeles, California 90045

LANA NGUYEN, California Department of Parks and Recreation, 8471 North Coast Highway, Laguna Beach, California 92651

ABSTRACT: From 1950 through 2016, the Western Snowy Plover (Charadrius nivosus nivosus) did not nest on Los Angeles County beaches. But between 16 April and 21 May 2017, up to four pairs initiated five nests in Los Angeles County and one at a new site in Orange County. Between 12 May and 15 June 2017, ten eggs hatched, including one incubated at a wildlife care facility. From these, a minimum of three chicks were known to have fledged. One nest was destroyed by high winds, a second by either high winds or possibly human disturbance. Plovers selected sites within or adjacent to areas protected by fenced enclosures. We protected all nests with mini-exclosures. We suggest that this recolonization was due to the combination of protection of potential nesting sites, protection of individual nests, and exceptional recent productivity at other nesting sites in southern California. The fenced enclosures provided essential protection from vehicles and encouraged accumulation of beach wrack around the nests and feeding areas. Additionally, once nests were established, the placement of exclosures provided essential protection from native predators and pet and feral dogs and cats. Protection with both fencing and exclosures, combined with management to minimize disturbance, will be essential for maintaining this new nesting population.

Prior to 1950, the Western Snowy Plover (Charadrius nivosus nivosus) nested on sandy beaches and dunes in Los Angeles and Orange counties (Grinnell and Miller 1944, Western Foundation for Vertebrate Zoology unpubl. data, Allen et al. 2016). The sites included Redondo, Ballona (Venice/ Playa Del Rey), Los Angeles, and Malibu beaches in Los Angeles County (Allen et al. 2016) and Sunset Beach, Bolsa Chica Beach, Newport Beach, and Balboa Beach in Orange County (Page and Stenzel 1981). Subsequently, the plovers' ability to nest on beaches was greatly reduced through increased disturbance by sand grooming (raking), recreation, predators, and regular vehicular traffic, including beach grooming, maintenance, and driving of police and lifeguard trucks. The last active nest of a plover on a Los Angeles County beach was reported at Manhattan Beach in 1949 (Stager 1949). Since then, no cases of a plover nesting within Los Angeles County have been documented (Allen et al. 2016), although the county's beaches were not systematically surveyed during the nesting season from the 1970s to 2004 
(G. Page pers. comm. 2010, Ryan et al. 2010). Nevertheless, plovers have continued to winter on Los Angeles County beaches, typically occurring from early July to April (Page et al. 1986, Ryan et al. 2010). In Orange County, a single pair nested in dunes along Balboa Beach in the city of Newport Beach in 2008, 2009, and 2013 (P. Knapp, R. Griswold pers. comm.).

Following the population's designation as threatened, the U.S. Fish and Wildlife Service (USFWS 2012) listed six segments of sandy beach in Los Angeles County and three segments of sandy beach in Orange County as critical habitat for the Snowy Plover, largely because of the importance of these sites for wintering. Los Angeles and Orange counties are within Recovery Unit 6 (RU6) of the species' recovery plan (USFWS 2007). Goals of the plan include protecting wintering plovers from wrack removal, vehicles, pets, and human-related disturbance, and increasing the breeding population in RU6 to 500 individuals. This plan encourages activities that could lead to recolonization of currently unoccupied suitable habitat across Los Angeles and Orange counties (USFWS 2007). Despite these recommendations and a letter to beach managers in 2016 (USFWS 2016) most local beachmanagement agencies continue to allow wrack removal and vehicles flushing plovers, while restrictions on pets are only rarely enforced (Ryan et al. 2010).

Signage and protective enclosures made of wood-slat fencing and rope to cordon off areas of sandy beaches have been used elsewhere in California, including state parks around Monterey Bay in San Luis Obispo County, Oceano Dunes State Vehicular Recreational Area, and Coal Oil Point Reserve (Sandoval and Nielsen 2018, California State Parks 2018a, b). These provide a visual indicator demarking habitat plovers occupy for roosting and breeding, minimizing intrusion into those habitats. Mini-exclosures are also used, even though at some sites they have increased depredation on incubating adults and fledglings (Neuman et al. 2004). These problems, however, have not arisen at other sites (Dinsmore et al. 2014). Between 2005 and 2016 four of these enclosures were installed at Malibu Lagoon State Beach, Santa Monica Beach, and Dockweiler State Beach. These enclosures have provided protection from disturbance and allowed for habitat recovery (Ryan et al. 2010). Nesting Snowy Plovers recovered after the installation of enclosures at the Coal Oil Point Reserve (Sandoval and Nielsen 2018). Here we document the return of nesting by Snowy Plovers to sandy beaches on the mainland of Los Angeles and Orange counties after similar management.

\section{METHODS}

In 2007, we began year-round systematic surveys for roosting plovers on sandy beaches suitable for plover breeding in Los Angeles County and extended these surveys to Orange County in 2014 (Ryan et al. 2017). Prior to this, Point Reyes Bird Observatory organized surveys in winter from 1979 to 1986 (Page et al. 1986) and continued subsequently though not all beaches were surveyed in all years. Then beach segments with known roosts were surveyed twice per year as part of the USFWS's winter and breeding season "window surveys," starting with Los Angeles County in 2004 and Orange County in 2008. Surveys concentrated on areas of known roosting, and not all beaches were covered prior to 2007 (Ryan et al. 2017). Since 
2007 beach surveys have consisted of trained volunteers and permitted biologists surveying suitable habitat four times per year and roosts monthly (Ryan et al. 2017).

As part of these efforts, fenced enclosures (rope, wood-slat, or plastic, open on one side with signage) have been installed at four sites. Since 2008, the California Department of Parks and Recreation has maintained an enclosure measuring 120-180 × 30-90 m at Malibu (34 ${ }^{\circ} 1^{\prime} 5^{\prime \prime} \mathrm{N}$, $118^{\circ} 40^{\prime}$ 53" W). Two sites are in Santa Monica: one installed by the city

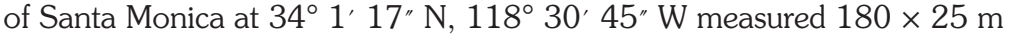
in 2005 and 2006 and $90 \times 25$ m subsequently; the other, installed at $34^{\circ}$ $1^{\prime} 27^{\prime \prime}$ N, $118^{\circ} 30^{\prime}$ 57" W in 2016 in the Bay Foundation's Santa Monica Beach Restoration Area, measures $143 \times 50 \mathrm{~m}$. The fourth, at Dockweiler

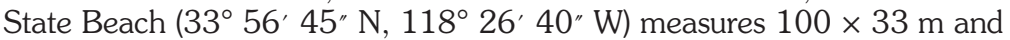
has been maintained since 2010 by the Los Angeles County Department of Beaches and Harbors (Johnston et al. 2017, Ryan et al. 2017). Enclosures have helped reduce human disturbance and have encouraged wrack and dune habitats to begin forming (Johnston et al. 2017, Ryan et al. 2017). Additionally, the Bay Foundation's site in Santa Monica was seeded with native dune plants in 2016 with the goals of restoring coastal strand vegetation, increasing ecologically functional habitat on Los Angeles County beaches, and evaluating those beaches for their potential to improve coastal resilience (Johnston et al. 2017).

In order to protect nests found from common predators, we deployed mini-exclosures. We constructed these from $5 \times 10-\mathrm{cm}$ wire mesh, measuring $70 \mathrm{~cm} \times 70 \mathrm{~cm} \times 70 \mathrm{~cm}$. The bottom $10 \mathrm{~cm}$ was sunk into the sand and anchored with aluminum tent stakes. Following installation, we observed the plovers to ensure that the adults returned to the nest within 20 minutes.

\section{RESULTS}

\section{Malibu Lagoon State Beach}

Nest A. On 21 April 2017 C. Jauregui and J. Realegeno detected three plovers (one color-banded; right: blue/blue, left red/red [RR:BB]) and found a nest scrape with no eggs. On 28 April T. P. Ryan, F. Franken, and V. Franken-Ruiz observed one egg, two males, and one female (RR:BB) (Table 1). On 29 April, Dellith, J. King, and T. P. Ryan observed one egg (Figure 1) and installed a mini-exclosure over the nest. King, M. Moser, and M. Ryan extended the "symbolic" (rope) fencing 50 feet from the nest to provide a buffer from the public beach. Monitors observed one male and one female (RR:BB). On 5 May, Dellith and D. Lefer observed the exclosure was damaged, likely by people, or by a heavy object being blown into it. Unusually high winds from 18:00 on 27 April to 01:00 on 30 April had sustained speeds of $70 \mathrm{~km} / \mathrm{hr}$ and gusts to $88 \mathrm{~km} / \mathrm{hr}$. Between 30 April and 5 May the plovers abandoned this nest. We consider nest $A$ to have been unsuccessful.

Nest B. On 4 May 2017, G. Murayama and L. Loeher found a second nest with at least one egg, with an incubating male and the same female (RR:BB) (Table 1). With D. Lefer, J. King, and D. Deppe, they returned on 5 May to extend the symbolic fencing around the nest. That day Dellith 
Table 1 Outcomes of Snowy Plover Nests in Coastal Los Angeles and Orange Counties, 2017

\begin{tabular}{|c|c|c|c|c|c|c|}
\hline Location/ID & $\begin{array}{l}\text { Encountered/ } \\
\text { Estimated } \\
\text { Initiation }\end{array}$ & $\begin{array}{l}\text { Protected by/ } \\
\text { Date }\end{array}$ & Eggs & $\begin{array}{l}\text { Hatched/ } \\
\text { Date }\end{array}$ & Fledged & Outcome \\
\hline Malibu $\mathrm{A}^{a}$ & $\begin{array}{l}28 \text { April/ } \\
27 \text { April }\end{array}$ & $\begin{array}{c}\text { Enclosure }^{b} \text { and } \\
\text { exclosure } \\
29 \text { April }\end{array}$ & 1 & 0 & 0 & $\begin{array}{l}\text { Eggs destroyed by } \\
\text { wind or human } \\
\text { disturbance }\end{array}$ \\
\hline Malibu B ${ }^{a}$ & $\begin{array}{l}4 \text { May/ } \\
1-3 \text { May }\end{array}$ & $\begin{array}{c}\text { Enclosure }^{b} \text { and } \\
\text { exclosure }\end{array}$ & 3 & $\begin{array}{c}3 \\
1-4 \text { June }\end{array}$ & 1 & $\begin{array}{l}1 \text { chick fledged, others } \\
\text { likely depredated }\end{array}$ \\
\hline Santa Monica & $\begin{array}{l}\text { 18 April/ } \\
17 \text { April }\end{array}$ & $\begin{array}{l}5 \text { May } \\
\text { Enclosure and } \\
\text { exclosure } \\
24 \text { April }\end{array}$ & 3 & 0 & 0 & $\begin{array}{c}\text { Eggs destroyed by } \\
\text { wind }\end{array}$ \\
\hline Dockweiler A & $\begin{array}{l}\text { 27 April/ } \\
\text { 11-12 April }\end{array}$ & $\begin{array}{l}\text { Enclosure and } \\
\text { exclosure } \\
27 \text { April }\end{array}$ & 3 & $\begin{array}{c}3 \\
12-13 \\
\text { May }\end{array}$ & 0 & $\begin{array}{l}3 \text { chicks depredated by } \\
\text { Ring-billed Gull }\end{array}$ \\
\hline Dockweiler B & $\begin{array}{l}9 \text { May/ } \\
6 \text { May }\end{array}$ & $\begin{array}{c}\text { Enclosure and } \\
\text { exclosure } \\
10 \text { May }\end{array}$ & 3 & $\begin{array}{c}3 \\
\text { 6-8 June }\end{array}$ & 1 & $\begin{array}{l}1 \text { chick fledged, others } \\
\text { likely depredated }\end{array}$ \\
\hline $\begin{array}{l}\text { Huntington } \\
\text { State Beach }\end{array}$ & $\begin{array}{l}21 \text { May/ } \\
15 \text { May }\end{array}$ & $\begin{array}{c}\text { Enclosurec and } \\
\text { exclosure } \\
21 \text { May }\end{array}$ & 1 & $\begin{array}{c}1^{d} \\
15 \text { June }\end{array}$ & 1 & $\begin{array}{l}1 \text { chick fledged, with } \\
\text { human assistance }\end{array}$ \\
\hline Total & 6 nests & & 14 & 10 & 3 & \\
\hline
\end{tabular}

a Same banded female associated with both nests.

${ }^{b}$ Existing enclosure extended to provide 15-m buffer for nest.

${ }^{c}$ No existing enclosure; a ring of cones of radius $30 \mathrm{~m}$ was placed as an enclosure on $21 \mathrm{May}$, followed by an $45 \times 45-\mathrm{m}$ wood slat-fencing on 23 May.

${ }^{d}$ Adult plovers abandoned the nest, egg collected and incubated, chick hatched and fledged in captivity.

and Lefer also installed an exclosure around the nest, which contained two eggs and was being attended by both adults. On 9 May, Lefer completed installation of the remaining symbolic fencing and observed an adult plover incubating. Monitors observed incubation between 9 May and 3 June. They observed one egg on 1 June, an adult with two chicks and one egg in the nest on 3 June, and a smaller chick with an adult and no eggs in the nest on 4 June. We infer that three eggs successfully hatched between 1 and 4 June. Monitors observed a single plover chick on 9 June and 14 July. On 30 June two additional juvenile, possibly migrants, were observed; they were chased by the male. Monitors observed one juvenile plover attended by the male on 7 and 14 July. We consider nest B to have been successful.

\section{Santa Monica State Beach: The Bay Foundation's Santa Monica Beach Restoration Area}

Cooper found a single nest with one egg at this site on 18 April (Table 1, Figure 2). On 24 April, Dellith, T. P. Ryan, Plauzoles, and Johnston installed an exclosure around the nest, which then contained three eggs and was being attended by two males, one incubating eggs. After the exclosure was installed, the male immediately returned to the nest before the biolo- 


\section{RETURN OF BEACH-NESTING SNOWY PLOVERS TO LOS ANGELES}

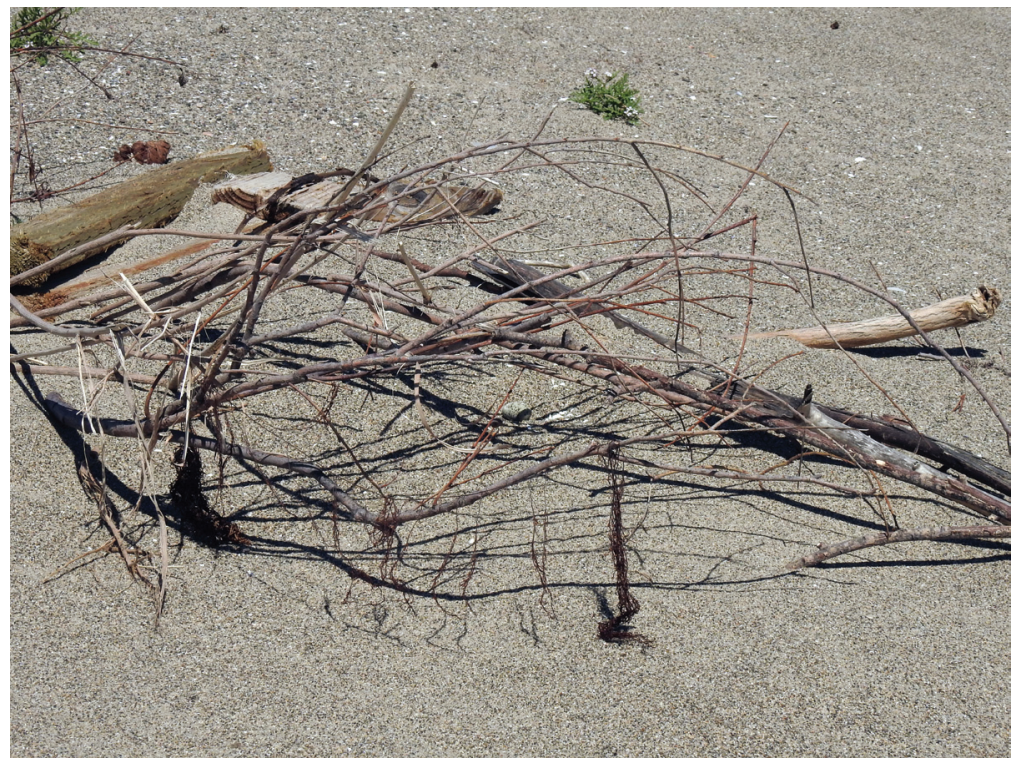

Figure 1. A single Snowy Plover egg in a unique nest covered with driftwood at Malibu Lagoon State Beach, Los Angeles County, California, 29 April 2017.

Photo by Thomas P. Ryan

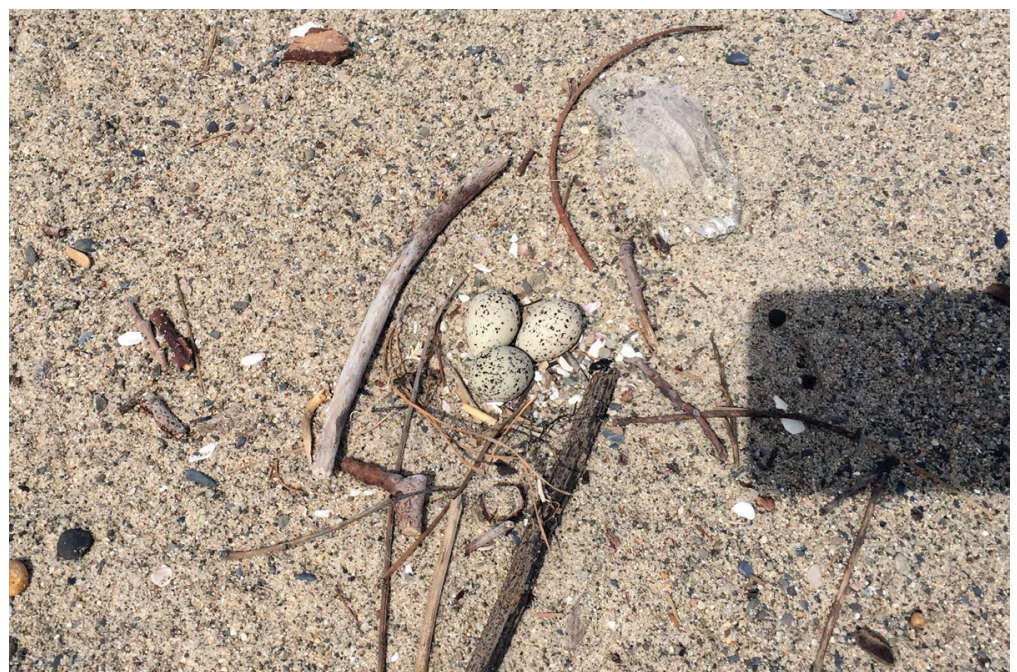

Figure 2. The first Snowy Plover nest located along the mainland coast of Los Angeles County since 1949, at Santa Monica by Daniel S. Cooper, 18 April 2017. 
gists had exited the protected site (Figure 3). It remained on the nest during the subsequent observation period. Informative signage was posted around the perimeter of the restoration area restricting access to the area. In this area the unusually strong wind extended from 20:00 on 27 April to 02:00 on 29 April; sustained winds of $56 \mathrm{~km} / \mathrm{hr}$ with gusts to $79 \mathrm{~km} / \mathrm{hr}$ were recorded at the Santa Monica Pier, 1.5 miles south. The resulting blowing sand covered the nest and eggs. Cooper found no nest, eggs, or adult plovers within the restoration area on 30 April, but did observe three plovers at the top of the beach slope. On 4 May Plauzoles observed two females and one adult male plover south of the restoration area, approximately 15 m south of Lifeguard Tower 4, near the wrack line. We consider this nest to have been unsuccessful.

\section{Dockweiler State Beach Plover Enclosure}

Nest A. Vigallon found a plover nest with two or three eggs on 27 April 2017; later that day, K. Kughen and T. P. Ryan installed an exclosure and observed three eggs (Table 1). The nest was incubated by a female; three males were nearby. We estimate a nest-initiation date of 11-12 April as early-season clutches typically hatch on day 31 (Warriner et al. 1986). Three eggs hatched between 12 and 13 May. However, Vigallon observed the depredation of all three chicks by a Ring-billed Gull (Larus delawarensis) on 15 May. We consider nest A to have been unsuccessful.

Nest B. P. Prichard found a second nest with two eggs on 9 May 2017. The next day, S. West, Vigallon, and Realegeno installed an exclosure and observed three eggs (Table 1). The nest was likely initiated on 6 May. Monitors observed two chicks and one egg on June 7. Three eggs hatched between 6 and 8 June. All three chicks survived until 11 June, but only one chick was observed after 14 June. Migrant plovers began arriving at the site on 27 June. On that day the chick was observed with the male, which chased other plovers. The chick was stretching its wings, a pre-fledging behavior, on 7 July and flapping and running on 13 July. A fledgling, likely the same individual, was observed with the plover flock on 20 July. We consider nest $B$ to have been successful.

\section{Huntington State Beach}

On 21 May 2017, B. Aird, C. George, and D. Lithgow, on a beach-wide survey, found a plover nest with one egg and a male and female in attendance at Huntington State Beach (Table 1). The park's personnel placed orange road cones and signage at a radius of $30 \mathrm{~m}$ around the nest, and Nguyen installed an exclosure around the nest at 12:35 that day. The plovers returned to the nest and were incubating within 15 minutes. On 23 May, the cones were replaced by a $45 \times 45$-m wood-slat wind fence that surrounded the nest on three sides. Adults incubated and foraged at the wrack line throughout its installation. No adults were observed incubating after 23 May. P. Knapp turned the egg up on 25 May in an attempt to determine if it was still being incubated. It remained turned up and no adults were observed. On 28 May he collected the egg, with approval from the USFWS, and delivered it to the Wetlands and Wildlife Care Center in Huntington Beach. It was placed in their incubator (Figure 4) and hatched on 15 June. The chick was banded 


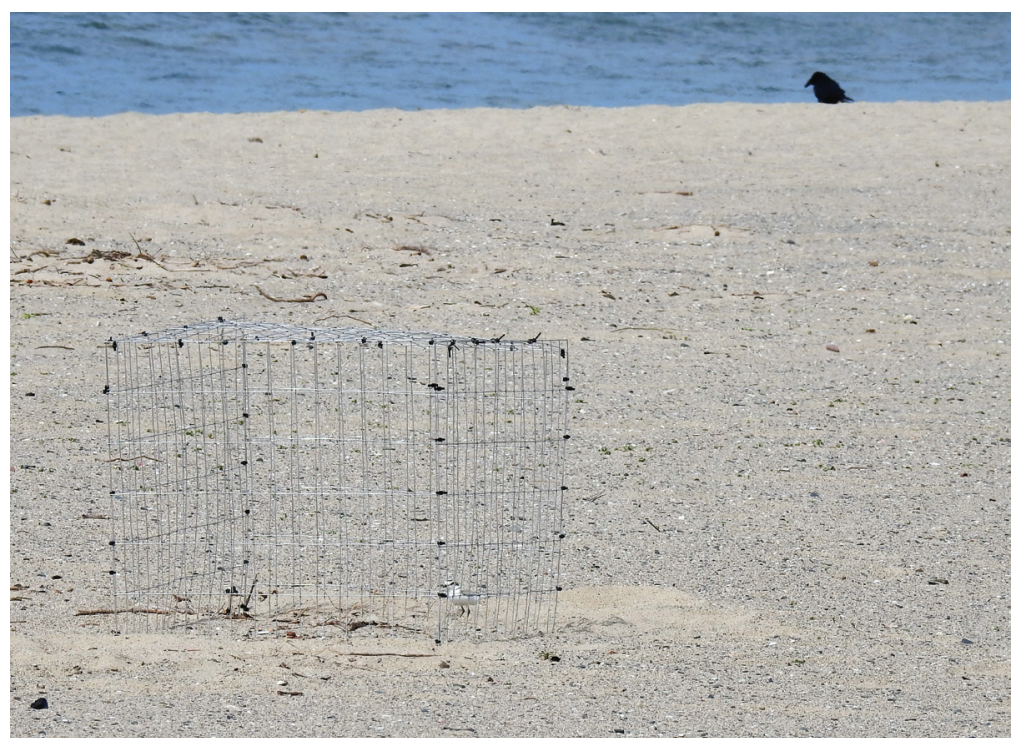

Figure 3. Snowy Plover upon return to its nest immediately after installation of a protective exclosure at Santa Monica, Los Angeles County, California, 24 April 2017. An American Crow was foraging in the background.

Photo by Thomas P. Ryan

and released at the Bolsa Chica State Ecological Reserve on 23 July (see photo on this issue's inside back cover). We consider this nest to have been successful with human assistance.

\section{DISCUSSION}

Between 16 April and 21 May 2017, plovers initiated five nests in Los Angeles County and one on a sandy outer beach in Orange County. In Los Angeles County, the plovers selected sites within or adjacent to areas already protected by enclosures. Our protecting all nests with exclosures of a standard design did not appear to influence mortality. One nest was

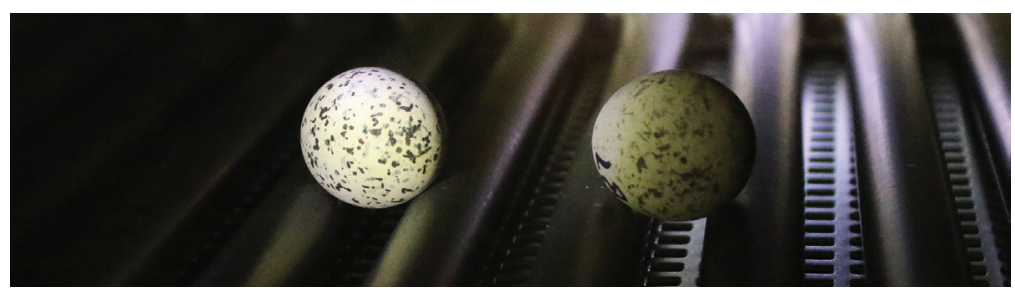

Figure 4. Snowy Plover eggs in the incubator at the Huntington Beach Wetlands and Wildlife Care Center, 17 June 2017.

Photo by Bruce Aird 
destroyed by high winds, a second either by high winds or possibly by human disturbance. Between 11 April and 15 May six nests containing a combined total of 14 eggs were initiated (Table 1). Between 12 May and 15 June 2017, ten eggs hatched, including one incubated at the Wetlands and Wildlife Care Center (Table 1). From these, a minimum of three chicks fledged, including one assisted by the Wetlands and Wildlife Care Center. These were the first nests with eggs or to produce young along the coast of mainland Los Angeles County since 1949.

The female (RR:BB) that nested at Malibu hatched in 2016 from a nest 210 km west-northwest at Oceano Dunes State Vehicular Recreation Area, San Luis Obispo County (A. Clark pers.comm.). She was detected at both Malibu and Zuma Beach (14 km to the west) in 2016 (F. Bidstrup pers. comm.). We suggest that these nestings were due to the combination of increased protection of the sites with enclosures, protection of nests with exclosures, and exceptional recent productivity elsewhere in southern California (USFWS unpubl. data, 2016).

Currently, most sandy beaches of mainland Los Angeles County are subject to daily grooming, vehicles operate within areas used for roosting and feeding by nonbreeding plovers, and pet regulations are rarely enforced (Ryan et al. 2010). Grooming removes naturally occurring kelp as well as trash and drastically reduces the population of invertebrates that have adapted to break down kelp, including prey items favored by plovers (Dugan et al. 2003, Page et al. 2009). The enclosure also provides a buffer to disturbance. Lafferty $(2001 \mathrm{a}, \mathrm{b})$ showed plovers are disturbed when approached within $30 \mathrm{~m}$ whether by dogs, humans, crows, and horses, with dogs disturbing the roosting plovers disproportionally. Additionally, Page et al. (1977) found that plovers left their nests 78\% of the time when people were within $50 \mathrm{~m}$ and $34 \%$ of the time when people were within $100 \mathrm{~m}$. Enclosures of wooden slats or symbolic fencing are used elsewhere, with notable success at Coal Oil Point Reserve in Santa Barbara where each year fencing is installed to protect both wintering $(300-400 \mathrm{~m})$ and breeding $(800 \mathrm{~m}$ ) plovers (Sandoval and Nielsen 2018). The placement of enclosures provided a buffer from disturbance and protection from vehicles, allowed natural beach topography to develop, and encouraged accumulation of beach wrack where plovers forage around the nests and feeding areas. Additionally, once nests were established, the placement of smaller exclosures provided protection from common beach predators such as the American Crow (Corvus brachyrhynchos), raccoon (Procyon lotor), and pet and feral dogs and cats, all of which continue to be observed at these sites. Although there have been reports of increased predation on fledglings and incubating adults from these types of exclosures at some sites (e.g., Neuman et al. 2004), we decided that without protection depredation of these nests was likely. We did not observe any mortality of adults or recent fledglings associated with the exclosure. All fledglings had moved away from the nest before they disappeared. We recommend that surveys and protective measures continue indefinitely. We further recommend the implementation of a minimum 150-m special-protection zone surrounding the center of plover roosts and nesting areas, in which grooming of and driving on beaches are curtailed or restricted with best-management practices, large recreational 
events are excluded, and enforcement of existing regulations regarding dogs on beaches is increased, as recommended by the USFWS (2016).

\section{ACKNOWLEDGMENTS}

We acknowledge the biologists, volunteers, and beach managers whose observations and quick response enabled the protection of these nests: Bruce Aird, Darlene Deppe, Facundo Franken, Vivi Franken-Ruiz, Chuck George, Ross Griswold, Carlos Jauregui, Jamie King, Peter Knapp, Katy Kughen, Danielle Lefer, Doug Lithgow, Larry Loeher, Melissa Moser, Grace Murayama, Lucien Plauzoles, Pam Prichard, Joyce Realegeno, Michelle Ryan, and Sabrina West. We thank the USFWS, California State Parks, California Department of Fish and Wildlife, The Bay Foundation, city of Santa Monica, Los Angeles Audubon, Orange County lifeguards, and Los Angeles County Department of Beaches and Harbors for their quick and effective reactions to these nest initiations and for providing staff to assist with their protection. We thank the many volunteers with the Snowy Plover Program of Los Angeles, Santa Monica Bay, South Bay, Sea and Sage, Pasadena, and San Fernando Audubon for their observations and assistance. We thank Francis Bidstrup and Amber Clark for their assistance with information on color bands. We thank Lynne Stenzel for her helpful comments in reviewing the draft. The findings and conclusions in this article are those of the authors and do not necessarily represent the views of the U.S. Fish and Wildlife Service.

\section{LITERATURE CITED}

Allen, L. W., Garrett, K. L., and Wimer, M. C. 2016. Los Angeles County Breeding Bird Atlas. Los Angeles Audubon Soc., Los Angeles.

California Department of Parks and Recreation (California State Parks). 2018a. Nesting of the California Least Tern and Western Snowy Plover at Oceano Dunes State Vehicular Recreation Area, San Luis Obispo County, California, 2018 Season. California Department of Parks and Recreation, Off-Highway Motor Vehicle Division, Oceano Dunes District, Oceano, California.; https://www. fws.gov/arcata/es/birds/wsp/documents/siteReports/California/2018\%20 Oceano\%20Dunes\%20State\%20Vehicular\%20Recreation\%20Area\%20Annual $\% 20$ nesting $\% 20$ report $\% 20$ of $\% 20$ western $\% 20$ snowy $\% 20$ plover $\% 20$ and $\% 20$ California\%20least\%20tern.pdf.

California Department of Parks and Recreation (California State Parks). 2018b. Annual Report for the Western Snowy Plover at San Luis Obispo Coast District in 2018. California State Parks, San Luis Obispo Coast District, San Simeon, California.; https://www.fws.gov/arcata/es/birds/wsp/documents/siteReports/ California/2018\%20San\%20Luis\%20Obispo\%20Coast\%20Annual\%20 WSP\%20Report.pdf.

Dinsmore, S. J., Lauten, D. J., Castelein, K. A., Gaines, E. P, and Stern, M. A. 2014. Predator exclosures, predator removal, and habitat improvement increase nest success of Snowy Plovers in Oregon, USA. Condor 116:619-628; doi 10.1650/CONDOR-14-7.1.

Dugan, J. E., Hubbard, D. M., McCrary, M. D., and Pierson, M. O. 2003. The response of macrofauna communities and shorebirds to macrophyte wrack subsidies on exposed sandy beaches of southern California. Estuarine, Coastal and Shelf Sciences 58S:25-40; doi 10.1016/S0272-7714(03)00045-3.

Grinnell, J., and Miller, A. H. 1944. The distribution of the birds of California. Pac. Coast Avifauna 27.

Johnston, K., Grubbs, M., and Abbott, R. 2017. Santa Monica Beach Restoration Pilot Project: Year 1 annual report. Prepared by The Bay Foundation for the city of Santa Monica, California Coastal Commission, Metabolic Studio, 
U.S. Environmental Protection Agency, and California Department of Parks and Recreation; www.santamonicabay.org/wp-content/uploads/2014/04/ SaMo-Beach-Project-Year-1-Report_FINAL_Aug2017.pdf.

Lafferty, K.D. 2001a. Birds at a Southern California beach: Seasonality, habitat use and disturbance by human activity. Biodiv. and Cons. 10:1949-1962; doi 10.1023/A:1013195504810.

Lafferty, K.D. 2001b. Disturbance to wintering western Snowy Plovers. Biol. Cons. 101:315-325; doi 10.1016/S0006-3207(01)00075-1.

Neuman, K., Page, G. W., Stenzel, L. E., Warriner, J. C., and Warriner, J. S. 2004. Effect of mammalian predator management on Snowy Plover breeding success. Waterbirds 27:257-263; doi 10.1675/1524-4695(2004)027[0257:EOMPM $\mathrm{O}] 2.0 . \mathrm{CO} ; 2$.

Page, G. W., and Stenzel, L. E. 1981. The breeding status of the Snowy Plover in California. W. Birds 12:1-40.

Page, G. W., Warriner, J. S., Warriner, J. C., and Halbeisen, R. M. 1977. Status of the Snowy Plover on the northern California coast. Part I: Reproductive timing and success. Calif. Dept. Fish and Game, Nongame Wildlife Investigations, Sacramento.

Page, G. W., Bidstrup, F. C., Ramer, R. J., and Stenzel, L. E. 1986. Distribution of wintering Snowy Plovers in California and adjacent states. W. Birds 17:145-170.

Page, G. W., Stenzel, L. E., Warriner, J. S., Warriner, J. C., and Paton, P. W. 2009. Snowy Plover (Charadrius alexandrinus), in The Birds of North America Online (A. Poole, ed.)., no. 154. Cornell Lab Ornithol., Ithaca, NY; doi 10.2173/ bna. 154 .

Ryan, T. P., Vigallon, S., Plauzoles, L. , Almdale, C., Montijo, R., and Magier, S. 2010. The Western Snowy Plover in Los Angeles County, California. Prepared for the Calif. Dept. Fish and Wildlife, Sacramento, by Ryan Ecological Consulting, Pasadena, CA.; https://nrm.dfg.ca.gov/documents/DocViewer.aspx.

Ryan, T. P., Vigallon, S., Plauzoles, L., Egger, C., Sheakley, S., Griswold, R., and Eastman, B. 2017. The Western Snowy Plover in Los Angeles and Orange counties, California: September 2014 to February 2017. Calif. Dept. Fish and Wildlife, Wildlife Branch, Nongame Wildlife Program Report 2017-01; www.fws. gov/arcata/es/birds/wsp/documents/siteReports/California/2014-2017\%20 Western\%20Snowy\%20Plover\%20in\%20Los\%20Angeles\%20and $\% 20$ Orange\%20Counties\%20CA_Ryan\%20et\%20al.pdf.

Sandoval, C., and Nielsen, J. 2018. 2017 final report on the Western Snowy Plover, Coal Oil Point Reserve, University of California, Santa Barbara, CA. Marine Science Institute, University of California, Santa Barbara, CA.; https://copr.nrs.ucsb. edu/sites/default/files/images/COPR_WSP\%20Report_2017_20180201.pdf.

Stager, K. E. 1949. Nesting season. Southern Pacific coast region. Audubon Field Notes 3:252.

U.S. Fish and Wildlife Service [USFWS]. 2007. Recovery plan for the Pacific coast population of the Western Snowy Plover (Charadrius alexandrinus nivosus): Vol. I, Recovery plan. U.S. Fish and Wildlife Service, Sacramento.

U.S. Fish and Wildlife Service [USFWS]. 2012. Endangered and threatened wildlife and plants: Revised designation of critical habitat for the Pacific coast population of the Western Snowy Plover; final rule. Fed. Register 77 (118): 36728-36869.

U.S. Fish and Wildlife Service [USFWS]. 2016. Protective measures for Western Snowy Plover on beaches in Los Angeles County, California. U.S. Fish and Wildlife Service, Ventura, CA.

Warriner, J. S., Warriner, J. C., Page, G. W., and Stenzel, L. E. 1986. Mating system and reproductive success of a small population of polygamous Snowy Plovers. Wilson Bull. 98:15-37. 